\title{
STUDI KASUS TERHADAP PERAN ORANGTUA DALAM MENANGANI ANAK BERKEBUTUHAN KHUSUS (AUTIS) DI DUSUN GARONGGANG DESA MARISI KECAMATAN ANGKOLA TIMUR
}

\author{
Nurhasanah Pardede $^{1}$, Rini Febrianti $^{2}$ \\ Bimbingan dan Konseling Universitas Muhammadiyah Tapanuli Selatan \\ nurhasanah.pardede@um-tapsel.ac.id
}

\begin{abstract}
Abstrak:
Penelitian ini dilakukan di Dusun Garonggang Desa Marisi Kecamatan Angkola Timur. Tujuan penelitian ini adalah untuk menggambarkan karakteristik yang dimiliki anak autis dan bagaimana mengetahui peran orangtua dalam menangani anak autis. Dalam penelitian ini penulis mengumpulkan data dengan turun langsung kelapangan dan melakukan teknik wawancara ketempat lokasi penelitian.

Responden dalam penelitian ini berjumlah 2 orang. Data yang diperoleh telah diolah dalam bentuk analisis studi kasus kualitatif deskriptif. Kesimpulan dari penelitian ini yaitu pada umumnya orangtua tidak mudah menerima kenyataan bahwa anaknya dinyatakan mengalami gangguan autis. Sikap mental yang belum atau tidak bisa menerima kenyataan ini seringkali berdampak pada kemampuan orangtua untuk menyesuaikan diri dengan khususnya keadaan anaknya.

Di satu sisi autis membutuhkan penangan yang sangat kompleks dan membutuhkan partisipasi dan peran aktif orangtua dalam banyak hal terkait dalam proses terapi. Sehingga perhatian terhadap orangtua dengan anak autis sangat penting, karena dengan penerimaan dan penyesuaian diri yang baik diharapkan peran aktif mereka semakin baik dalam berbagai upaya penanganan autis untuk menunjang keberhasilan terapi.
\end{abstract}

Kata Kunci : Peran Orangtua, Anak Autis, Angkola Timur 


\section{PENDAHULUAN}

Informasi saat ini mengenai autis dimasyarakat masih belum banyak dan belum mencakup lapisan masyarakat, bahkan banyak yang tidak tahu apa itu gangguan autis, informasi di masyarakat mengenai autis hanya diketahui masyarakat menengah keatas, sementara masyarakat yang menengah ke bawah masih banyak yang belum mengerti gejala-gejala dari gangguan autis dan cara penanggulangannya. Banyak orangtua menganggap keterlambatan berkomunikasi dan interaksi yang terjadi pada anaknya tersebut adalah hal yang wajar atau tidak menganggap gangguan autis yang terjadi pada anak mereka merupakan gejala gangguan mental atau gangguan jiwa.Sehingga anak-anak yang mengalami gangguan autis ini diperlukan tidak semestinya dengan kondisi yang mengkhwatirkan dan ini dapat memperburuk keadaan anak tersebut karena semakin terkucilkan bahkan di lingkungan keluarga.Anak berkebutuhan khusus sangat tidak diharapkan kehadirannya dalam suatu keluarga. Anak yang mengalami gangguan(anak berkebutuhan khusus) bisa saja berasal dari orangtua yang sehat, atau pun dari keluarga yang berada.

Anak Berkebutuhan Khusus (ABK) adalah seorang anak yang memiliki hambatan dalam aspek indra penglihatan, pendengaran, motorik fisik, mental, emosional dan sosial. Berbagai hambatan gangguan atau kelainan tersebut dapat diakibatkan dari berbagai faktor penyebab, diantaranya adalah dikarenakan adanya kerusakan bentuk/kondisi organ mata, telinga, fisik/tubuh yang berpengaruh pada gerakan, mental, emosional dan sosial sehingga mempengaruhi dalam aktivitas kehidupan sehari-hari.

Menurut (Puspita, 2004) beberapa bentuk kelainan dimaksud dapat dilihat dan diklasifikasikan dalam berat ringannya hambatan diantaranya: (A) tunanetra adalah anak atau seseorang yang mengalami kerusakan mata/kebutaan/tunanetra, (B) tunarungu adalah anak atau seseorang yang mengalami kerusakan organ/syaraf telinga berakibat kepada gtunarunguan , (C) tunagrahita adalah anak atau seseorang yang mengalami kerusakan atau gangguan pada organ/syaraf otak berakibat pada tunagrahita/pikiran, (D) tunadaksa adalah anak atau seseorang yang mengalami kerusakan pada organ tubuh dapat berupa bentuk kekakuan organ gerak, kelayuhan, gangguan koordinasi gerak, kontraktur sendi, (E) tunalaras adalah anak atau seseorang yang mengalami gangguan pada emosi dan sosial, (F) tunaganda adalah apabila seseorang anak mengalami gangguan/kelainan lebih dari satu macam misalnya tunanetra juga tunarungu dan autis adalah anak yang mengalami gangguan pada perkembangan koordinasi otak.

Setelah peneliti mengadakan observasi dilapangan, penelitian menemukan suatu kasus atau fenomena, yaitu seorang anak yang mengalami gangguan pada perkembangan koordinasi otak atau lebih sering dikenal dengan istilah autis, menurut penjelasan dari orangtuanya anak ini sudah lama mengalami gangguan perkembangan syaraf otak dan sering menyendiri dari orang lain. Gangguan ini terjadi ketika anaknya usia 2 tahun dan sampai sekarang masih sering menutup diri dari orang lain dan IQ rendah untuk menangkap suatu pelajaran.

Alasan peneliti memilih di Dusun Garonggang Desa Marisi Kecamatan Angkola Timur sebagai objek penelitian didasarkan pada sebagian masyarakat ada yang memiliki anak berkebutuhan khusua. Berdasarkan hal tersebut peneliti mengambil judul penelitian "Studi Kasus Terhadap Peran Orangtua Dalam Menangani Anak Berkebutuhan Khusus di Dusun Garonggang Desa Marisi Kecamatan Angkola Timur”

\section{METODE PENELITIAN}

Jenis penelitian ini adalah bersifat deskriptif yaitu penelitian yang berusaha untuk menuturkan pemecahan masalah yang ada sekarang berdasarkan data-data, menguji data, menganalisis dan menginterpretasikan.

Penelitian deskriptif menurut suharsimi arikunto "deskriptif adalah penelitian yang dimaksudkan untuk mengumpulkan informasi mengenai status suatu gejala menurut apa adanya pada saat penelitian dilakukan.

\section{HASIL DAN PEMBAHASAN}

Anak yang mengalami gangguan autis sangat tergantung kepada orang- orang yang tertentu atau orang-orang yang dekat dengannya seperti orangtua dan keluarga, yang mana anak 
autis ini sangatlah sulit menerima kehadiran orang baru di dekatnya. Oleh sebab itu peran oraangtua sangatlah penting untuk kesembuhan atau perkembangan anak autis dalam berinteraksi atau berkomunukasi dengan orangorangbaru.

Di Angkola Timur ada satu lembaga pendidikan yang peduli dengan anak autis yaitu SLB. Dimana lembaga pendidikan ini menangani dan mendidik pada perkembangan anak yang berkebutuhan khusus termasuk anak autis. Cara-cara mendidik anak-anak yang baik dan benar adalah bahwa mendidik anak dengan cara mendidik anak dengan cara disiplin tidak berarti menyelesaikan masalah-masalah anakanak didik.

Tugas utama dari keluarga bagi pendidikan anak adalah sebagai pelekat dasar pendidikan akhlak dan pandangan hidup keagamaan. Sifat dan tabiat anak sebagian besar diambil dari kedua orangtuanya dan dari anggota keluarga lain. Keluarga merupakan institusi yang paling penting pengaruhnya terhadap sosialisasi individu atau seseorang. Penerimaan ibu terhadap anak autis memerlukan pengetahuan yang luas tentang autis, sehingga ibu akan memahami arti dari autis yang sebenarnya. Sesuai dengan pemahaman seorang ibu, maka ibu akan menerima kondisi anak yang memberikan kasih sayang, perhatian, dan memahami anak sejak dini. Jadi pemahaman tentang autis terhadap penerimaan ibu yang mempunyai anak autis perlu dan penting.

Berdasarkan penelitian terhadap kedua orangtua kasus yang diteliti menyatakan perasaannya saat anak dinyatakan menderita autis dapat diuraikan sebagai berikut: "sejak awal peneliti bertanya-tanya seperti ada yang lain dengan diri anaknya, anaknya tidak dapat menatap mukan dan mata lawan berbicara, ternyata sejak usia tiga tahun anaknya sudah mengalami gangguan autis, dan mereka sebagai orantua suda berusa semampu dan sebisa mereka untuk kesembuhan anaknya”.

Dari hasil pengamatan di lapangan dapat disimpulkan bahwa awalnya orangtua yang memiliki anak penderita autis merasa terkejut dan bertanya mengapa hal itu menimpa anak saya, hingga orangtua berupaya mencari informasi yang lengkap seperti yang di lakukan orangtua anak autis diskusi dengan dokter maupun trapis. Dukungan lain yang diperlukan orangtua anak autis yaitu adanya dukungan jaringan sosial, sehingga orangtua tahu dan merasakan bahwa bukan dirinya saja yang mengalami masalah tersebut dan dia juga dapat berbagi pengalaman dengan orangtua lain yang memiliki anak yang sama seperti dirinya, kita juga dapat merasakan saat melakukan interaksi pada penelitian yang sudah dilakukan dengan anak autis peneniliti merasakan bahwa yang dikatakan beberapa para ahli mengenai hubungan sosial anak autis memang betul, jauh berbeda dengan kita berinteraksi dengan anak normal, yang dimana anak autis itu kalau kita sedang berkomunikasi dengan anak tersebut tidak ada ada kontak mata atau pun berbalas pertanyaan, dimana anak autis itu cenderung lebih pendiam dibanding dengan anak-anak normal.

Pada penelitian ini didapati keluarga yang memiliki anak autis karena terkadang mereka kewalahaan saat berkomunikasi dengan anaknya karena orangtua maupun keluarga lainnya sering tidak mengerti dengan apa yang anak autis katakan karena kurang jelas pengucapannya sehingga mereka kesulitan untuk mengartikan dan memahami kata-kata yang di ucapkan anak mereka, ini di buktikan dari pernyataan orangtua saat melakukan wawancara dengannya. Proses sosialisasi sangat dibutuhkan dalan pengasuhan anak autis. Karena dengan bersosialisasi anak autis dapat belajar tentang nilai, norma, pengetahuan dan keterampilan. Agar proses sosialisasi anak dapat dengan baik, maka dibutuhkan pihak-pihak yang membantu seorang anak autis belajar segala sesuatu yang kemudian menjadikannya dewasa (Narwoko, 2004). Pihak-pihak yang membantu anak autis dalam bersosial adalah: orangtua, keluarga, kelompok sebaya, sekolah.

Dari pendapat ahli di atas dapat disimpulkan bahwa anak-anak penyandang autis tidak menggunakan aturan untuk mengkomunikasikan emosinya. Yang mana Anak autis ini memiliki perasaan tetapi sulit baginya untuk mengekspresikannya. Sama seperti dia kesulitan untuk memahami hal yang sama pada dirinya. Para orangtua yang memiliki anak autis pasti menyadari hal ini bahwa memandang dan mengartikan wajah pada penderita autis tidak menimbulkan reaksi yang sama seperti orang-orang yang normal. Anak autis ini bermasalah pada perkembangan 
keterampilan sosialnya berkomukasi, tidak mampu memahami aturan dalam pergaulan, sehingga biasanya anak autis tidak mempunyai teman. Pada umumnya anak autis mengalami kesulitan dalam beradaptasi dengan lingkungan atau hal baru. Oleh karena itu peran orangtua sangat perlu untuk anak autis dalam berbagai bidang untuk perkembangan anaknya.

Metode-metode yang dipergunakan orang dewasa atau masyarakat dalam mempengaruhi proses sosialisasi anak, digolongkan menjadi tiga kategori yaitu: metode ganjaran atau hukuman, metode didacting teaching dan metode pemberian contoh (Ahmadi, 2002). Orangtua dalam melakukan pengasuhan denga menggunakan metode tersebut. Aturan dan tata tertib keluarga menerapkan konsep adanya imbalan dari setiap dari setiap kelakuan yang diberikan oleh anaknya, hukuman berupa sangsi hukuman dan ganjaran, aturan-aturan dibuat agar mereka sejak semula menyadari konsekuensi yang harus diterima. Hal seperti yang dijelaskan oleh (Soekarnto 2002) yang mengatakan bahwa arti penting dari komunikasi adalah pemberian tafsiran atas penyampaian informasi terhadap orang lain. Informasi yang disampaikan dapat berbentuk pembicaraan gerak tubuh dan sikap. Setelah menafsirkan, orang tersebut kemudian memberikan reaksi.

Dari penjelasan di atas kita dapat menyimpulkan bahwa dalam berkomunikasi selalu digunakan bahasa atau pembicaraan, juga digunakan gerak tubuh atau sikap. Penggunaan bahasa kita sebut sebagai komunikasi verbal. Sedangkan penggunaan anggota tubuh lain , selain suara kita sebut dengan komunikasi nonverbal. Pada proseses terjadi interaksi sosial, kedua bentuk komunikasi ini sama-sama penting untuk dipahami maknanya. Oleh karena itu kita sebagai orangtua atau orang normal kita harus memahami cara-cara berkomunikasi baik dengan anak berekebutuhan khusus maupun dengan orang normal, agar kita bisa berkomunikasi dengan orang-orang disekitar kita dan tidak salah artikan dengan perkataan maupun gerakannya.

Kemampuan verbal anak autis sangat terbatas, yaitu ketiadaan komunikasi timbal balik dengan lawan bicaranya, anak-anak ini hanya mampu menyampaikan sebatas keinginanya saja atau searah dengan kepentingannya sehingga tidak mampu mempertahankan pembicaraan yang panjang. Menurut (Puspita 2002) penyandang autis memiliki bentuk komunikasi yang tidak biasa, sebagaimana anak-anak non autis atau anakanak normal, komunikasi itu antara lain: mereka kesulitan untuk tanya jawab terutama yang menggunakan kalimat panjang, mereka sulit di ajak untuk berpindah topik ketopik lainnya, mereka tidak memahami bahasa atau kata-kata yang obyeknya belum pernah dilihatnya. Karena keterbatasan bahasa karea tidak memahami bahasa isyarat yang disampaikan orang lain.

Dari pendapat ahli di atas kita dapat menyimpulkan bahwa memng anak autis tidk dapat berbicara atau berkomunikasi secara panjang lebar. Yang mana anak autis ini hanya bisa berkomunikasi dengan keinginanya saja, anak auti ini bukan hanya sama orang lain cara dia berkomunikasi seperti itu namun untuk siapa saja dia sama seperti itu juga caranya berkomunikasi, harus sesuai dengan keinginannya tanpa memperdulikan lawan bicaranya.

\section{KESIMPULAN}

Dari hasil wawancara yang telah dilakukan kepada responden, informan dapat ditarik kesimpulan sebagai berikut:

1. Gambaran anak autis responden I

Secara psikologi responden I punya keinginan untuk sembuh dari gangguan autis yang dideritanya. Tapi karena keterlambatan dalam berpikirnya dan selalu menutup diri dari orang lain dia kesulitan untuk melawan autis yang di deritanya, mungkin ini salah satunya penyebab utama untuk dirinya dan orangtuanya dalam melakukan upaya pengobatan.

2. Gambaran anak autis responden II

Secara psikologi responden II ini memiliki keinginan untuk sembuh dari gangguan autis yang dideritanya. Buktinya sudah terlihat jelas dari keinginannya untuk terus melanjutkan pendidikanya walaupun dengan segala keterbatasan dan kekurangan yang dimilikinya. Dia begitu bersemangat untuk sembuh walaupun dia tidak bisa sepenuhnya seperti dengan temantemannya yang normal. Tapi orangtuanya selalu berusaha memberikan yang terbaik 
untuk anaknya dan orangtuanya juga tidak pernah bosan untuk mencaritau tempat

\section{Saran}

berobat maupun untuk tempat terapi.

Berdasarkan hasil pengamatan atau yang dirasakan orangtua responden untuk kesembuhan anaknya yang begitu orangtua idam-idamkan selama ini. Terdapat beberapa hal yang dapat dijadikan sebagai saran kepada pihak-pihak yang terkait seperti anak, orangtua, pembaca dan penulis selanjutnya dan lain-lain.

1. Responden penelitian

a. Responden I: Disarankan kepada responden I untuk terus bersamangat dalam menjalankan upaya pengobatan selanjutnya agar bisa sembuh dari gangguan autis yang dideritanya selama ini, dan terus bersemangat untuk selalu belajar supaya lebih pintar lagi.

b. Responden II: Disarankan kepada responden II untuk terus lebih giat belajar dan menjalankan terapi atau pengobatan selanjutnya. Supaya bisa cepat sembuh dan lebih pintar lagi.

2. Informan penelitian

a. Informan I: Disarankan kepada informan I sebagai orangtua agar tetap bersyukur dan sabar dalam mendampingi dan menangani anak autis untuk menjalankan pengobatan selanjutnya agar impian orangtua akan kesembuhan anak bisa tercapai dan terwujut walaupun tidak seutuhnya.

b. Informan II: Disarankan kepada informan II sebagai kakak harus lebih sabar dalam membantu dan memberi motivasi untuk adiknya agar bisa bergabung dengan orang lain.

c. Informan III: Disankan kapada informan III sebagai teman harus lebih sabar lagi untuk berteman dengan anak autis walaupun terkadang merasa jengkel berteman dengannya karna kurang respon.

3. Saran Bagi Pembaca

Semoga hasil penelitian ini dapat dijadikan sebagai resferinsi atau sumber informasi dan materi yang dapat menambah wawasan atau ilmu pengetahuan dengan masalah yang akan diteliti dan juga dapat diamalkan dalam keseharian pembaca.

\section{DAFTAR PUSTAKA}

Farhan Setyawan, 2010. Puspita, 2002. Pola Penanganan Anak Autis. (Skiripsi).

, Faisal Yatim. 2003.Pola Penanganan Anak Autis. (Skiripsi).

Fitri Rahayu,2014.YPAC, 2013.Kemampuan Komunikasi Anak Autis Dalam Interaksi Sosial (Skiripsi)

Ika Miftahul Rahmah, 2016, Puspita. 2004, Peran Orangtua Untuk Meningkatkan Komunikasi Anak Autis (Skripsi)

Lexy J.Moleong, 2007. Sugiyono, 2005.Metode Penelitian Kualitatif, Remaja Rosdakarya Offiset. Bandung

, Basuki (2006).Metode Penelitian Kualitatif, Remaja Rosdakarya Offiset. Bandung.

Misbah Usmar Lubis, 2009.Kun Maryati, 2006.Penyesuaian Diri Orangtua yang memiliki Anak Autis. (Skripsi)

,Prasetyono, 2008. Penyesuaian Diri Orangtua yang memiliki Anak Autis. (Skripsi)

Puji Astuti, Joko Yuwono. 2014. Mengenal Karakteristik Anak Berkebutuhan Khusus. Jakarta

,Kartono, 2000. Mengenal Karakteristik Anak BerkebutuhanKhusus. Jakarta Puspita, 2004. Mengenal Karakteristik Anak Berkebutuhan Khusus. Jakarta, Sujarwanto, 2005. Mengenal Karakteristik Anak Berkebutuhan Khusus. Jakarta

Randi Wahyu Marianto, Durand. 2007. Peran Orangtua dalam Menangani Anak Autis. Vol. 3 No. 1 Februari 2016 (Jurnal)

, Candra Gautama, 2000. Peran Orangtua dalam Menangani AnakAutis. Vol. 3 No. 1 Februari 2016 (Jurnal) 